\title{
Assessment of Arsenic Induced DNA Fragmentation by using Comet Assay
}

\section{Akram Z*, Mahjabeen I and Kayani MA}

Cancer Genetics Research Group, Department of Biosciences, COMSATS Institute of Information Technology, Islamabad, Pakistan

\begin{abstract}
Arsenic is metalloid present in measureable quantity in air, water, and soil through natural and anthropogenic sources. It is neurotoxic, hepatotoxic and genotoxic effects, variety of health problems have been associated to arsenic exposure. This review was designed to investigate the possible association between arsenic exposure and DNA damage in animals and humans using comet assay. Total 28 studies were selected for measuring DNA damage by comet assay. Trend of significance in tail length and tail moment was observed using regression analysis. Due to limited number of studies available the regression analysis was non-significant. Individually each study suggested a significant increase in tail moment and tail length in a dose and time-dependent manner. Overall trend observed in this review is the positive association between arsenic exposure either experimentally or occupationally and DNA damage. This initial effort may provide future guideline for the assessment of DNA fragmentation using comet assay.
\end{abstract}

Keywords: Genotoxicity; DNA damage; Comet assay; Arsenic

\section{Introduction}

Arsenic is a very common and widely distributed environmental toxicant [1] derived from natural and anthropogenic sources [2]. It can be carcinogenic depending on its exposure time, concentration, and chemical form [3]. Trivalent arsenic is 60 times more toxic than pentavalent arsenic [4,5]. Arsenic has been declared as class A human carcinogen by United States Environmental Protection Agency (EPA) [6]. At higher concentrations, arsenic acted as lethal agent, while prolonged exposure at lower concentration is associated with various human malignancies including lungs, kidneys, liver, skin abnormalities and cardiovascular diseases $[1,7,8]$. Underground water in many regions of the world is contaminated with high concentrations of arsenic [9]. Although United States Environmental Protection Agency (EPA) and World Health Organization (WHO) have revised drinking water standards for arsenic from $50 \mu \mathrm{g} / \mathrm{l}$ to $10 \mu \mathrm{g} / \mathrm{l}$ [6]. Millions of people are still in contact with arsenic through drinking water at concentrations greater than the standard value [10-12]. Arsenic related health problems have been reported worldwide but worst conditions have been observed in Asia, specifically in Bangladesh [3].

Arsenic is well known for the production of reactive oxygen species (ROS) $[13,14]$. In normal healthy body ROS and antioxidants remain in balance, and when this balance is disturbed, oxidative stress occurs [15]. Oxidative stress causes oxidative damage to cellular DNA, lipids and proteins, which contributes to cell death [16-20]. Almost 200 enzymes are inactivated by arsenic toxicity, mostly involved in DNA replication, repair and cellular energy pathways. These enzymes have greater affinity to substituted phosphate in high energy compounds as ATP results in the production of useless energy [5,21-23]. So, the genotoxicity of arsenic does not communicate directly to DNA, however, indirectly it affects DNA by production of reactive oxygen species (ROS) or deregulation of DNA repair enzymes [13,24].

Single cell gel electrophoresis or comet assay is widely accepted as a simple, sensitive and standard technique for the detection of DNA damage at single cell level. Genotoxicity of various industrial chemicals, agrochemicals, pharmaceuticals and pollutants can be assessed with comet assay [25]. This assay can detect DNA damage in different cell types such as in skeletal muscle cells [26], cumulus cells [27], eosinophils [28] and ovarian cells [29]. It has also been used to detect DNA damage in blood of Polish copper smelter workers occupationally exposed to inorganic arsenic [30].
The association between arsenic exposure and DNA damage is a matter of concern. Purpose of this review is to provide quantitative estimate of DNA damage in subjects exposed to arsenic either experimentally/cell lines, occupationally or naturally. Main focus of present review was based on potential relationship between the arsenic concentration, exposure time, and DNA damage which was detected by comet assay.

\section{Methodology}

The aim of present review is to investigate the toxic effects of arsenic on DNA fragmentation in blood, liver, reproductive organs and in different types of cell lines.

\section{Literature search}

A comprehensive search strategy was used to identify all the related studies. Database of Pubmed from 2000-2015 was searched and following key words were used: comet assay, blood, liver tissue, ovarian tissue, testicular tissue and arsenic induced DNA damage. The search was restricted to English language. Only full length articles were included, unpublished data and abstracts were not considered.

\section{Inclusion and exclusion criteria}

The following inclusion criteria are used to select articles for this review: (1) studies using both human and animal models were included (2) studies using the evaluation of DNA fragmentation by comet assay were included (3) studies using the assessment of arsenic genotoxicity in liver, blood, ovarian, testicular tissues and cell lines were also included in this review. Exclusion criteria used for this review as follows: (1) studies assessing the DNA damage by techniques other than

*Corresponding author: Akram Z, Cancer Genetics Research Group, Department of Biosciences, COMSATS Institute of Information Technology, Islamabad, Pakistan, Tel: 092519235914; E-mail: zee1524@yahoo.com

Received February 18, 2016; Accepted March 16, 2016; Published March 18 2016

Citation: Akram Z, Mahjabeen I, Kayani MA (2016) Assessment of Arsenic Induced DNA Fragmentation by using Comet Assay. J Carcinogene Mutagene 7: 258. doi:10.4172/2157-2518.1000258

Copyright: (C) 2016 Akram Z, et al. This is an open-access article distributed under the terms of the Creative Commons Attribution License, which permits unrestricted use, distribution, and reproduction in any medium, provided the original author and source are credited. 
comet assay were not included in this study(2) studies on metals other than arsenic were excluded (3) abstracts were also excluded from this analysis.

\section{Statistical analysis}

Data are expressed as Mean \pm SEM. Exposure time and doses were considered. Different parameters of comet assay were measured in twenty eight studies of this review. In thirteen studies (11 for blood, 1 for liver, 1 for ovary: (Table 1) the statistical values were given for comet parameter. Arsenic induced DNA damage in cell lines of different cancers was studied in fifteen studies. Regression analysis was performed to assess the correlation between exposure time and comet parameters (tail length and tail moment) (Table 1).

\section{Results}

\section{Literature survey}

This database yielded total 3316 articles for comet assay in blood, liver tissues, ovarian tissue, testicular tissue and cell lines. Of the retrieved articles 3277 were research articles while 39 were review articles. Most of the review articles were relevant to blood and cell lines and only 2 were related to liver. These 39 review articles were excluded from the present study.

Remaining 3277 articles were investigated to sort out the data for blood, liver, ovarian, testicular tissue and cell lines. Out of which we found 2707 articles for blood, 277 for liver tissue, 6 for ovarian tissue, 14 for testicular tissue and 273 for cell lines. In 273 articles of cell lines only 165 human related articles were investigated, out of which just 56 articles were found with full text. Next major step was to extract arsenic related data from these articles. A total of 82 articles were relevant to arsenic, in which twenty one studies used blood, three used liver tissue, one used ovarian tissue, one for testicular tissue and 56 for cell lines. In twenty one articles of blood, ten were excluded from the study, six were abstracts, two articles were in Chinese language, and two articles used cell culture for damage assessment. Therefore, a total of eleven articles were selected for comet assay in blood. In liver tissue three relevant articles were found, of which two were excluded one was abstract and other article was an in-vitro study. Therefore only one article was selected for liver tissue. We found only one article for ovarian tissue and one for testicular tissue for this study, but article of testicular tissue was excluded because of the availability of abstract only. Fifty six articles were retrieved for cell lines of different cancers. Out of which 41 were non-related to study criteria, they were excluded and only fifteen articles of cell lines were selected for this study. Thus, a total of twenty eight studies: eleven blood study, one liver and one ovarian tissue and fifteen cell lines study were included in this review (Figure 1).

\section{Characteristics of study}

Total twenty eight studies were included in this review and these were not confined to any particular experimental model. Fifteen studies were related to cell line and remaining thirteen were related to blood/tissue. Regression analysis was done in thirteen studies (Table 1). Among which seven studies have reported different parameters of comet assay in blood of humans. Two studies have been reported for blood of mice, one for rat and one for fish sample. One study has been reported for ovarian tissue of rat and one for liver of fish. The study of Ahmad et al. has been shown twice because it contained data both for blood and liver tissue. In all these studies different parameters of comet assay has been observed in order to evaluate DNA fragmentation induced by arsenic toxicity either by experimental

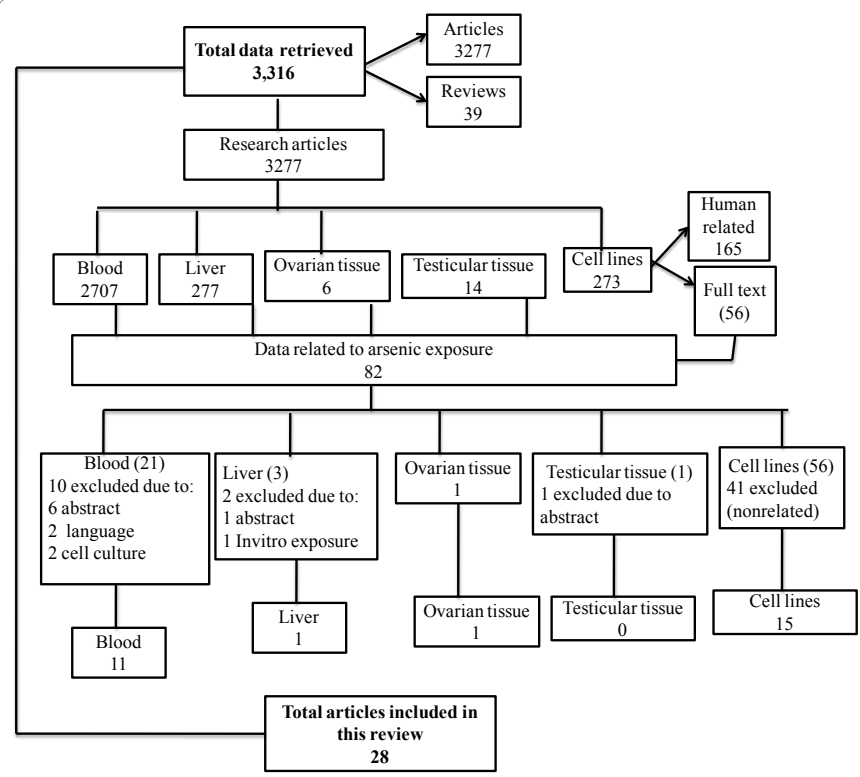

Figure 1: Flow chart showing exclusion inclusion criteria of studies used in this review.

\begin{tabular}{|c|c|c|c|l|l|}
\hline No. & Author & Year & Model & Tissue & Observed parameter \\
\hline 1 & Flora et al. [31-32] & 2004 & Rat & Blood & Tail length \\
\hline 2 & Yanez et al. [33] & 2003 & Human & Blood & Tail length, tail moment \\
\hline 3 & Vuyyuri et al. [34] & 2006 & Human & Blood & Tail length \\
\hline 4 & Banerjee et al. [35] & 2008 & Human & Blood & \%tail DNA, olive tail moment,tail length \\
\hline 5 & Ahmad et al. [36-39] & 2011 & Fish & Liver & \% tail DNA \\
\hline 6 & Basu et al. [24] & 2005 & Human & Blood & \%tail DNA, tail length,tail moment,comet length \\
\hline 7 & Palus et al. [30] & 2005 & Human & Blood & Tail moment \\
\hline 8 & Palus et al. [38] & 2006 & Mice & Blood & Tail moment \\
\hline 9 & Mendez-Gomez et al. [36] & 2008 & Human & Blood & Tail length \\
\hline 10 & Akram et al. [29] & 2009 & Rat & Ovary & \%DNA tail, tail length,tail moment,olive tail moment \\
\hline 11 & Ahmad et al. [36-39] & 2011 & Fish & Liver & \% tail DNA \\
\hline 12 & Ahmad et al. [39] & 2011 & Fish & Blood & \% tail DNA \\
\hline 13 & Flora et al. [32] & 2012 & Mice & Blood & Tail length \\
\hline 14 & Jasso-Pineda [37] & 2012 & Human & Blood & Tail moment \\
\hline
\end{tabular}

Table 1: Characteristics of studies having arsenic induced DNA damage assessed by comet assay. 
Citation: Akram Z, Mahjabeen I, Kayani MA (2016) Assessment of Arsenic Induced DNA Fragmentation by using Comet Assay. J Carcinogene Mutagene 7: 258. doi:10.4172/2157-2518.1000258

Page 3 of 7

mean or by living in natural environment. Major comet parameters used in these studies, as a marker of DNA damage, were comet tail length, tail moment and \%tail DNA. In remaining 15 studies of cell lines, different comet parameters were studied but statistical values were not given, rather data was presented either in graphical form or as a photograph of comet to show the intensity of DNA damage in these cell lines. Due to lack of sufficient statistical values no further analysis was made between these studies.

\section{Detail description of findings}

Detailed description of thirteen studies of blood and tissues included in this review is given in Table 2. Two studies of Flora et al. $[31,32]$ are included in this study. Significant DNA damage was assessed in mice [32], while in rats no data was reported [31]. Similar extent of DNA damage was observed in children living in mining site of Villa de Paz with high arsenic contamination compared with children living in Matechuala with low arsenic contamination [33]. People of West Bengal have high arsenic exposure and therefore express significant DNA damage in blood compared to unexposed or less exposed population [24]. Poland and South Indian population are occupationally exposed to arsenic and have shown DNA fragmentation compared to unexposed population [30,34]. People of India (Murshidabad) exposed to arsenic contaminated drinking water express greater extent of DNA migration compared to unexposed population [35]. Mendez-Gomez et al. [36] and Jasso-Pineda et al. [37] studied different arsenic exposed areas in Mexico and observed greater fragmentation of DNA damage in areas located nearest to arsenic source (Table 2).

Arsenic induced genotoxicity has also been calculated in animals exposed to different doses of arsenic and significant DNA damage has been observed in mice [38] rats [29], and fish [39].

Arsenic is involved in the promotion of different cancers. Therefore, cell lines of different cancer were investigated. Fifteen studies in different cell lines were included in this review (Table 3 ).

In all these studies positive trend of DNA damage with increased doses of arsenic exposure was reported. Most of the data was presented as a graph or picture to show the DNA fragmentation. Only four authors had given values for tail length and tail moment $[8,40-42]$. DNA damage was increased with increasing dose of arsenic (Table 4).

\begin{tabular}{|c|c|c|c|c|c|c|c|c|c|}
\hline Number & Author & Year & Model & Tissue & Doses/area & Exposure & Comet parameter & Mean & Observed effects \\
\hline 1 & Flora et al. [31] & 2004 & Rat & Blood & $10 \mathrm{mgKg}-1$ & 5 days/wk/12wk & tail length & no data & heavy DNA damage \\
\hline \multirow[t]{2}{*}{2} & Yanez et al. [33] & 2003 & Human & Blood & Villa de la Paz & \pm 2 years & $\begin{array}{l}\text { tail length, tail } \\
\text { moment }\end{array}$ & $67.6 \mu \mathrm{m}, 6.8$ & significant damage \\
\hline & & & & & Matehuala & & & $41.7 \mu \mathrm{m}, 3.2$ & in Villa de la Paz \\
\hline \multirow[t]{4}{*}{3} & Basu et al. [24] & 2005 & Human & Blood & West Bengal & \pm 5 years & \%DNA tail & $59.74 \pm 10.54 \mu \mathrm{m}$ & \\
\hline & & & & & & & Tail length & $58.68 \pm 10.23 \mu \mathrm{m}$ & DNA damage \\
\hline & & & & & & & Tail moment & $42.31 \pm 11.58$ & \\
\hline & & & & & & & Comet length & $83.33 \pm 15.51 \mu \mathrm{m}$ & \\
\hline 4 & Palus et al. [30] & 2005 & Human & Blood & Poland & \pm 18years & Tail moment & $13.2 \times 10-3$ & significant damage \\
\hline \multirow[t]{3}{*}{5} & Palus et al. [38] & 2006 & Mice & Blood & $50 \mu \mathrm{g} / \mathrm{L}$ & $3,6,12$ months & Tail moment & $0.14 \pm 0.11,0.02 \pm 0.02,0.14 \pm 0.07$ & significant damage \\
\hline & & & & & $200 \mu \mathrm{g} / \mathrm{L}$ & $3,6,12$ months & & $0.16 \pm 0.12,0.03 \pm 0.01,0.02 \pm 0.01$ & at $50 \mu \mathrm{g} / \mathrm{L}$ \\
\hline & & & & & $500 \mu \mathrm{g} / \mathrm{L}$ & $3,6,12$ months & & $0.12 \pm 0.06,0.03 \pm 0.01,0.03 \pm 0.03$ & \\
\hline 6 & Vuyyuri et al. [34] & 2006 & Human & Blood & India & minimum 3 year & Tail length & $14.95 \pm 0.21 \mu \mathrm{m}$ & signficant damage \\
\hline \multirow[t]{3}{*}{7} & Banerjee et al. [35] & 2008 & Human & Blood & Murshidabad & \pm 10 year & Olive tail moment & $2.76 \pm 1.39$ & significant damage \\
\hline & & & & & & & $\%$ DNA tail & $14.05 \pm 4.71$ & \\
\hline & & & & & & & Tail length & $11.85 \pm 5.51$ & \\
\hline \multirow[t]{4}{*}{8} & $\begin{array}{l}\text { endez-Gomez et } \\
\text { al. [36] }\end{array}$ & 2008 & Human & Blood & $\begin{array}{l}\text { Mexico(3 school } \\
\text { around arsenic } \\
\text { location) }\end{array}$ & $\begin{array}{l}\text { minimum } 6 \\
\text { month }\end{array}$ & Tail length & & \\
\hline & & & & & Distant & & & 29.2 & significant damage \\
\hline & & & & & Intermediate & & & 25.3 & in nearest compared \\
\hline & & & & & Nearest & & & 28.6 & to intermediate \\
\hline \multirow[t]{4}{*}{9} & Akram et al. [29] & 2009 & Rat & Ovary & $50,100,200 p p m$ & 28 days & Tail moment & $0.09 \pm 0.01,0.45 \pm 0.05,0.50 \pm 0.05$ & significant damage \\
\hline & & & & & & & Tail length & $17.98 \pm 1.39,20.61 \pm 1.45,22.12 \pm 1.49$ & maximum at high dose \\
\hline & & & & & & & $\%$ DNA tail & $0.43 \pm 0.02,1.73 \pm 0.08,2.12 \pm 0.11$ & \\
\hline & & & & & & & Olive tail moment & $0.08 \pm 0.01,0.40 \pm 0.04,0.50 \pm 0.04$ & \\
\hline \multirow[t]{3}{*}{10} & Ahmad et al. [39] & 2011 & Fish & Liver & 3ppm & $48,96,192 \mathrm{hrs}$ & $\%$ DNA in tail & $>10,>20,>20$ & significant, with \\
\hline & & & & & 28ppm & & & $>30,>40,>30$ & maximum damage \\
\hline & & & & & $56 \mathrm{ppm}$ & & & $>40,>50,>40$ & at $96 \mathrm{hr}$ \\
\hline \multirow[t]{3}{*}{11} & Ahmad et al. [39] & 2011 & Fish & Blood & 3ppm & $48,96,192 \mathrm{hrs}$ & $\%$ DNA tail & $>10,>10,>10$ & significant, with \\
\hline & & & & & 28ppm & & & $>20,>30,>20$ & maximum damage \\
\hline & & & & & 56ppm & & & $>30,>40,>30$ & at $96 \mathrm{hr}$ \\
\hline 12 & Flora et al. [32] & 2012 & Mice & Blood & $5 \mathrm{mg} \mathrm{l-1}$ & 28 weeks & Tail length & $>150 \mu \mathrm{m}$ & significant damage \\
\hline \multirow[t]{4}{*}{13} & Jasso-Pineda [37] & 2012 & Human & Blood & $\begin{array}{l}\text { San Luis Potosi } \\
\text { state( } 3 \text { communities) }\end{array}$ & & & & \\
\hline & & & & & community 1 & $\pm 6 y e a r$ & Tail moment & $5.2 \pm 0.6$ & significant damage \\
\hline & & & & & community 2 & $\pm 6 y e a r$ & & $3.5 \pm 0.4$ & \\
\hline & & & & & community 3 & \pm 7 year & & $2.5 \pm 0.4$ & \\
\hline
\end{tabular}

Table 2: Detailed description of findings observed in present review. 


\begin{tabular}{|c|c|c|c|c|}
\hline No & Author & Sample & Arsenic species & Dose /Exposure \\
\hline 1 & Gatti et al., 2014 [40] & non-smal cell lung cancer A549 & Arsenic trioxide & $80 \mu \mathrm{M}, 3 \mathrm{hrs}$ \\
\hline 2 & Yoo et al., 2009 [41] & HCC cell line SK-Hep-1 & Sodium arsenite & $2 \mu \mathrm{M}, 48 \mathrm{~h}$ \\
\hline 3 & Yedjou and Tchounwou, 2007 [42] & HL-60 promyelocytic leukemia cell line & Arsenic trioxide & $10 \mu \mathrm{g} / \mathrm{mL}$ \\
\hline 4 & Dopp et al., 2008 [43] & Primary human hepatocytes & Sodium arsenite/arsenate & $0.1-500 \mu \mathrm{M}, 1 \mathrm{hr}$ \\
\hline 5 & Graham et al., $2014[44,45]$ & Induced plurpotent stem cell (IPS) & Arsenic trioxide & $1,3,5,7,9 \mu \mathrm{g} / \mathrm{ml}, 24 \mathrm{hrs}$ \\
\hline 6 & Jan et al., 2006 [46] & NB4- human promyelocytic leukemia cell line & Arsenic trioxide & $1 \mu \mathrm{M}$ \\
\hline 7 & Kryeziu et al., 2013 [47] & NSCLC cell lines A549 & Arsenic trioxide & $100 \mu \mathrm{mol} / \mathrm{L}, 6 \mathrm{hrs}$ \\
\hline 8 & Liu et al., 2010 [48] & glioblastoma multiforme U87 cells & Arsenic trioxide & $6 \mu \mathrm{M}, 4 \mathrm{~h}$ \\
\hline 9 & Nakamura et al., 2013 [49] & osteosarcoma cell line 143B & Arsenic trioxide & $3 \mu \mathrm{M}$ \\
\hline 10 & Pu et al., 2007 [50] & NB4-human promyelocytic leukemia cell line & Sodium arsenite & $0.2 \mu \mathrm{M}, 1 \mathrm{~h}$ and $24 \mathrm{hrs}$ \\
\hline 11 & Qin et al., 2008 [51] & human keratinocyte cell line (HaCat) & Sodium arsenite & $10 \mu \mathrm{M}, 24 \mathrm{hrs}$ \\
\hline 12 & Stevens et al., 2010 [52] & Human colon cancer (HT-29) & Arsenic trioxide & $2,4,6,8,10,12 \mu \mathrm{g} / \mathrm{mL}, 24 \mathrm{~h}$ \\
\hline 13 & Wneck et al., 2011 [53] & bladder urothelial cells (UROtsa) & Monomethylarsonous acid & $50 \mathrm{nM}, 12$ weeks \\
\hline 14 & Xie et al., 2014 [2] & lung fibroblast/epithelial cells & Sodium arsenite & $0.5,1,5,10 \mu \mathrm{M}, 24 / 120 \mathrm{hrs}$ \\
\hline 15 & Chai et al., 2007 [8] & Human uroepithelial cell line (SV-HUC-1) & Sodium arsenite & $1,2,4,8,10 \mu \mathrm{M}, 48 \mathrm{hrs}$ \\
\hline
\end{tabular}

Table 3: Detailed description of cell lines studies selected for this review.

\begin{tabular}{|l|l|l|l|}
\hline Author & Year & Cell lines & \multicolumn{2}{l|}{ Comet parameter } \\
\hline & & & Tail length \\
\hline Gatti et al. [40] & 2014 & Non-smal cell lung cancer A549 & - \\
\hline Yoo et al. [41] & 2009 & HCC cell line SK-Hep-1 & 255.92 \\
\hline Chai et al. [8] & 2007 & Human uroepithelial cell line (SV-HUC-1) & $65.91,71.27,98.01$ \\
\hline Yedjou and Tchounwou [42] & 2007 & HL-60 promyelocytic leukemia cell line & $3,17,24$ \\
\hline
\end{tabular}

Table 4: Statistical values of comet parameters in cell lines of different cancers.

\section{Statistical facts}

This review is not confined to any specific experimental model. Human, rats, mice and fish have been used as a model in selected studies. Humans had natural exposure or occupational exposure to arsenic by living or working in that particular environment. In seven studies of human population of different arsenic contaminated areas, arsenic exposure ranged from 6 months to 18 years. Among which only in one study, the exposure time was not been reported [37]. In these seven studies significant increase has been reported in comet tail length and tail moment of exposed individuals compared to unexposed or less exposed individuals. Comet tail length and tail moment in different populations of exposed areas is shown in figure 2 observed in this review.

Regression analysis was performed in studies of human population to assess the correlation between exposure time and extent of DNA damage in exposed individuals. Regression analysis is shown in figure 3. Regression analysis in human samples revealed a non-significant relationship between exposure time and comet parameters. Regression analysis was not performed for animal studies because of very few studies found; only one study was reported for blood of mice, ovarian tissue of rat and blood and liver tissue of fish. In these three studies animals were exposed to different doses of arsenic for different time periods. Although the parameters of comet varied in these studies but individually each study suggested a significant damage with high doses compared to low doses (Figure 3).

The complete picture of arsenic deposition either in blood, water, urine, or tissue observed in this review is shown in table 5 . In six studies arsenic deposition was measured in urine, in 3 studies arsenic was measured in blood and water and in one study arsenic was measured in ovary, liver, nail, hair, dust and soil sample. In observed studies arsenic deposition differed in different samples with respect to the doses for animals and with respect to the location of arsenic for

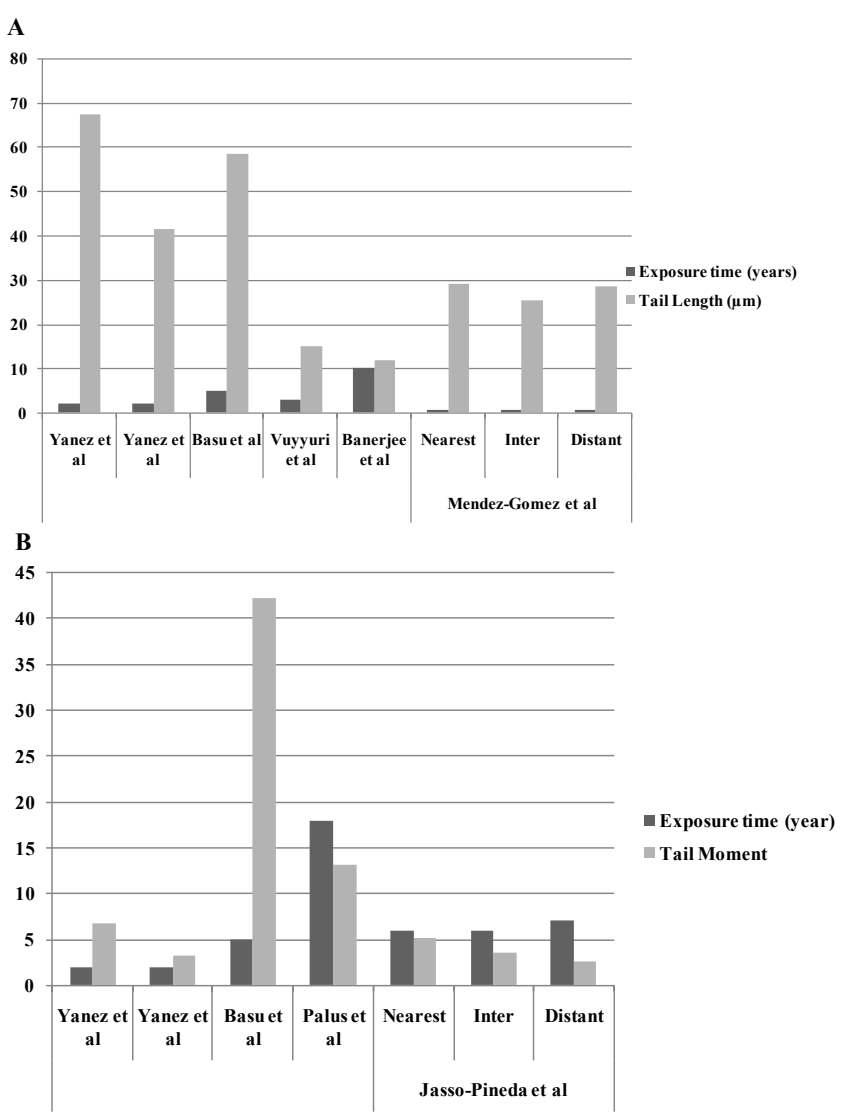

Figure 2: Overall relationship between tail length $(A)$, tail moment $(B)$ and exposure time in different populations. 

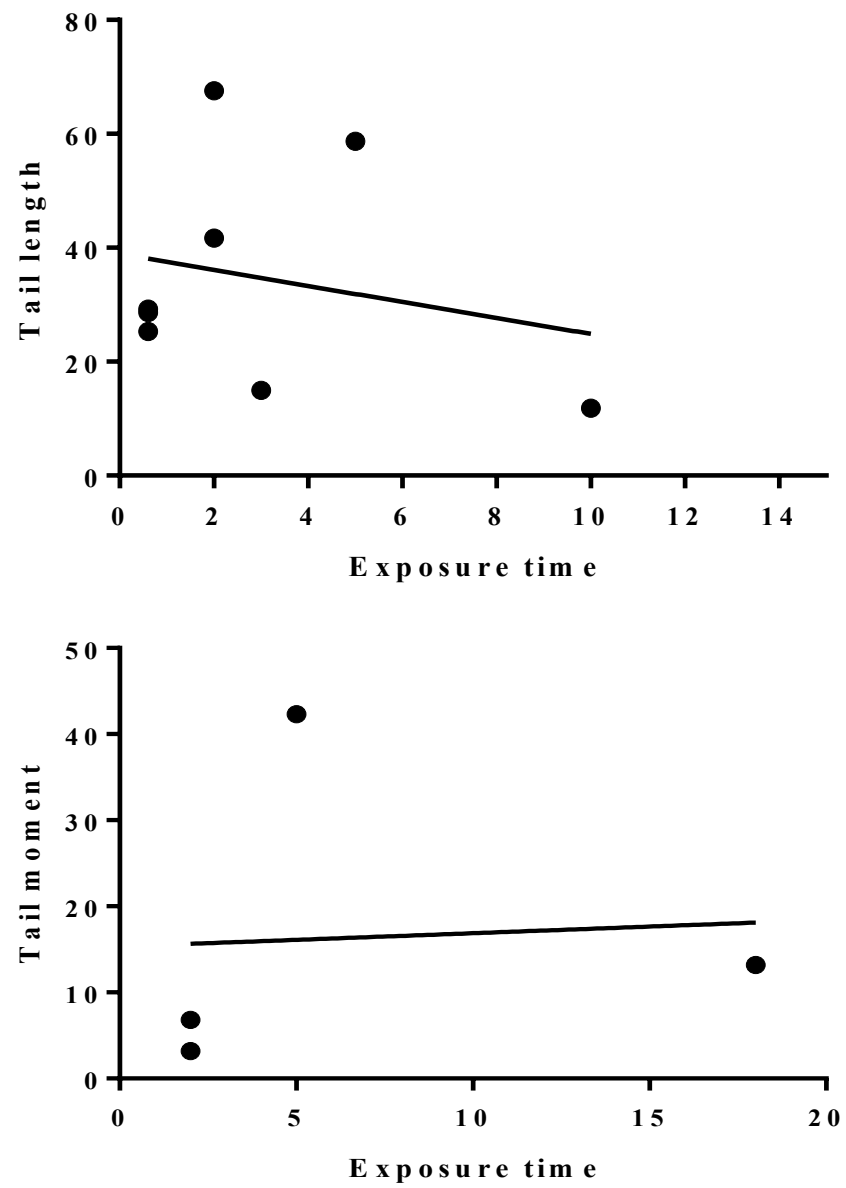

Figure 3: Calculated regression line showing non-significant relation between exposure time to arsenic and comet parameters in human samples. human population. Marked relationship can be observed between the deposition of arsenic and DNA fragmentation in comet tail length and tail moment (Table 5).

\section{Discussion}

In this review, arsenic induced genotoxocity was measured by comet assay in blood/tissue sample or cell lines. The in-vivo or invitro genotoxicity induced by different ways chemicals, pesticides, insecticides, environmental pollutants, or endocrine disruptors has been widely studied by using comet assay [25]. The most frequent parameter used to measure DNA damage was comet tail length and tail moment.

This review has explored the association of arsenic exposure and DNA fragmentation in humans, animal model and in cell lines. In human studies the population is chronically and naturally exposed to arsenic either by living in close proximity to arsenic source, by drinking arsenic contaminated water, by inhaling the arsenic dust or occupationally exposed to arsenic. The animals are exposed to different doses. Dose, concentration, exposure time, distance affects the arsenic induced genotoxicity. DNA damage has been detected in ovarian tissue in a dose-dependent manner [29]. Similarly higher extent of DNA fragmentation has also been reported in different communities of San Luis Potosi State [37] and in different schools of Mexico [36] located at different distances from arsenic smelter area.

Major limitation in this review is the limited number of studies examining the association of arsenic exposure and DNA fragmentation. In human studies, DNA damage was measured by comet assay only in blood sample, and there was no tissue related study. In six studies of animals, four were carried out in blood sample, one in ovarian tissue and only one in liver tissue. While in cell line studies only four had shown the statistical values of comet assay indicating DNA damage, while in remaining eleven studies DNA damage was expressed either as a graph or microphotograph. Due to lack of statistical data it is not possible to perform any further analysis in cell line studies. Regression analysis

\begin{tabular}{|c|c|c|c|c|c|c|c|c|c|c|c|c|c|c|}
\hline \multirow[t]{2}{*}{ Number } & \multirow[t]{2}{*}{ Author } & \multirow[t]{2}{*}{ Year } & \multirow[t]{2}{*}{ Model } & \multirow[t]{2}{*}{ Area } & \multirow[t]{2}{*}{ Exposure } & \multirow[t]{2}{*}{ Dose } & \multicolumn{6}{|c|}{ Arsenic concentration } & \multicolumn{2}{|c|}{ Comet parameter } \\
\hline & & & & & & & dust/soil & water & urine & blood & liver & ovary & tail length & tail moment \\
\hline 1 & Flora et al. [31] & 2004 & Rat & - & $12 w k$ & $10 \mathrm{mgKg}-1$ & & & & $3.5 \mu \mathrm{g} / \mathrm{ml}$ & $2.5 \mu \mathrm{g} / \mathrm{g}$ & - & - & - \\
\hline \multirow[t]{2}{*}{2} & Yanez et al. [33] & 2003 & Human & Villa de la Paz & \pm 2 years & _ & $2462 \mathrm{mg} / \mathrm{kg}$ & & $136 \mu \mathrm{g} / \mathrm{gc}$ & - & _ & _ & 67.6 & 6.8 \\
\hline & & & & Matehuala & & - & $1019 \mathrm{mg} / \mathrm{kg}$ & & $34 \mu \mathrm{g} / \mathrm{gc}$ & - & - & - & 41.7 & 3.2 \\
\hline 3 & Basu et al. [24] & 2005 & Human & West Bengal & \pm 5 years & - & - & $247.12 \mu \mathrm{g} / \mathrm{L}$ & $259.75 \mu \mathrm{g} / \mathrm{L}$ & - & - & - & 58.68 & 42.31 \\
\hline 4 & Palus et al. [30] & 2005 & Human & Poland & \pm 18 years & _ & _ & & $60 \mu \mathrm{g} / \mathrm{L}$ & _ & _ & _ & _ & 13.2 \\
\hline 5 & Vuyyuri et al. [34] & 2006 & Human & India & $\min 3$ year & - & - & & & $56.76 \mu \mathrm{g} / \mathrm{L}$ & - & - & 14.95 & - \\
\hline 6 & Banerjee et al. [35] & 2008 & Human & Murshidabad & \pm 10 year & - & - & $5.04 \mu \mathrm{g} / \mathrm{L}$ & $296.03 \mu \mathrm{g} / \mathrm{L}$ & & - & - & 11.85 & - \\
\hline \multirow[t]{4}{*}{7} & $\begin{array}{l}\text { Mendez-Gomez et } \\
\text { al. [36] }\end{array}$ & 2008 & Human & $\begin{array}{l}\text { Mexico(around } \\
\text { arsenic location) }\end{array}$ & min 6 month & & $\mu \mathrm{g} / \mathrm{g}$ & $\mu g / L$ & $\mu g / L$ & & & & - & - \\
\hline & & & & Distant & - & - & 21.8 & 26.05 & 143 & - & - & - & 29.2 & - \\
\hline & & & & Intermediate & - & - & 75.6 & 6.8 & 100 & - & - & - & 25.3 & - \\
\hline & & & & Nearest & - & - & 155.6 & 13.16 & 115 & - & - & - & 28.6 & - \\
\hline \multirow[t]{3}{*}{8} & Akram et al. [29] & 2009 & Rat & - & 28days & 50ppm & - & - & - & - & - & $1 \mu \mathrm{g} / \mathrm{mg}$ & 17.9 & 0.09 \\
\hline & & & & - & - & 100ppm & - & - & - & - & - & $1-2 \mu \mathrm{g} / \mathrm{mg}$ & 20.61 & 0.45 \\
\hline & & & & - & - & 200ppm & - & - & - & - & - & $3-4 \mu \mathrm{g} / \mathrm{mg}$ & 22.12 & 0.5 \\
\hline 9 & Flora et al. [32] & 2012 & Mice & - & $28 \mathrm{wk}$ & $5 \mathrm{mg} \mathrm{l}-1$ & - & - & & $7-8 \mathrm{ng} / \mathrm{ml}-1$ & $5-6 \mu \mathrm{g} / \mathrm{g}-1$ & & $100-150$ & - \\
\hline \multirow[t]{4}{*}{10} & Jasso-Pineda [37] & 2012 & Human & $\begin{array}{l}\text { San Luis Potosi } \\
\text { state }\end{array}$ & & & & & $\mu \mathrm{g} / \mathrm{gc}$ & & & & & - \\
\hline & & & & $\begin{array}{l}\text { community } \\
1 \text { (nearest) }\end{array}$ & \pm yyears & - & - & - & 44.5 & - & - & - & - & 5.2 \\
\hline & & & & community 2 (inter) & \pm 6 years & - & - & - & 16.8 & - & - & - & - & 3.5 \\
\hline & & & & community 3(distant) & \pm 7 years & - & - & - & 12.8 & - & - & - & - & 2.5 \\
\hline
\end{tabular}

Table 5: Arsenic deposition in different biological samples estimated in studies of present review. 
Citation: Akram Z, Mahjabeen I, Kayani MA (2016) Assessment of Arsenic Induced DNA Fragmentation by using Comet Assay. J Carcinogene Mutagene 7: 258. doi:10.4172/2157-2518.1000258

Page 6 of 7

was performed in human studies to correlate time exposure and DNA damage, which was statistically non-significant. Nevertheless, each study has shown greater extent of DNA damage in exposed individuals compared to unexposed or less exposed population(s). The difference was even clear when two areas of same city were considered, which were located at variable distance from arsenic source.

Animal studies were not enough in number to perform statistical analysis. There was only single study evaluating DNA damage in ovarian tissue of rat [29] and in liver of fish [39] exposed to different doses of arsenic and indicated the increased extent of DNA damage with all doses, specifically at high dose levels. In studies of current review, arsenic concentration was measured in blood, liver, ovary and water. Levels of arsenic in these measured parameters has shown greater extent of deposition in region closely located to arsenic source in case of human and with high doses in case of experimental animals.

Present study suggests a possible association between arsenic exposure and DNA damage either in humans, experimental animals or in cell lines. Overall trend from all the studies propose that the genotoxicity of arsenic is dose-dependent as well as time-dependent. Nevertheless, small numbers of studies are the limitation factor to illuminate the complete and clearer picture of arsenic genotoxicity but this initial effort can make a future guideline for the assessment of DNA fragmentation using comet assay.

\section{References}

1. Alarifi S, Ali D, Alkahtani S, Siddiqui MA, Ali BA, et al. (2013) Arsenic trioxidemediated oxidative stress and genotoxicity in human hepatocellular carcinoma cells. Onco Targets Ther 6: 75-84.

2. Xie H, Huang S, Martin S, Wise JP Sr (2014) Arsenic is cytotoxic and genotoxic to primary human lung cells. Mutat Res Genet Toxicol Environ Mutagen 760: 33-41.

3. Hossain MF (2006) Arsenic contamination in Bangladesh: an overview. Agri Ecosys Environ 113: 1-16.

4. Csanaky I, Németi B, Gregus Z (2003) Dose-dependent biotransformation of arsenite in rats--not S-adenosylmethionine depletion impairs arsenic methylation at high dose. Toxicology 183: 77-91.

5. Ratnaike RN (2003) Acute and chronic arsenic toxicity. Postgrad Med J 79: 391-396.

6. Tchounwou PB, Centeno JA, Patlolla AK (2004) Arsenic toxicity, mutagenesis, and carcinogenesis--a health risk assessment and management approach. Mol Cell Biochem 255: 47-55.

7. Hughes MF (2002) Arsenic toxicity and potential mechanisms of action. Toxico Lett 133: 1-16.

8. Chai CY, Huang YC, Hung WC, Kang WY, Chen WT (2007) Arsenic saltinduced DNA damage and expression of mutant p53 and COX-2 proteins in SV-40 immortalized human uroepithelial cells. Mutagenesis 22: 403-408.

9. Brinkel J, Khan MH, Kraemer A (2009) A systematic review of arsenic exposure and its social and mental health effects with special reference to Bangladesh. Int J Environ Res Public Health 6: 1609-1619.

10. Chan PC, Huff J (1997) Arsenic carcinogenesis in animals and in humans: mechanis-tic, experimental and epidemiological evidence. Environ Carcino Ecotoxicol Rev 15: 83-122.

11. Smith AH, Lingas EO, Rahman M (2000) Contamination of drinking-water by arsenic in Bangladesh: a public health emergency. Bull World Health Organ 78: 1093-1103.

12. World Health Organization (2001) Arsenic and arsenic compounds. International Programme on Chemical Safety. Environ Health Criteria: 224

13. Kitchin KT, Ahmad S (2003) Oxidative stress as a possible mode of action for arsenic carcinogenesis. Toxicol Lett 137: 3-13

14. Kumagai Y, Sumi D (2007) Arsenic: signal transduction, transcription factor, and biotransformation involved in cellular response and toxicity. Annu Rev Pharmacol Toxicol 47: 243-262.
15. Agarwal A, Gupta S, Sharma RK (2005) Role of oxidative stress in female reproduction. Reprod Biol Endocrinol 3: 28.

16. Ahmad S, Kitchin KT, Cullen WR (2000) Arsenic species that cause release of iron from ferritin and generation of activated oxygen. Arch Biochem Biophys 382: 195-202.

17. Brockmöller J, Cascorbi I, Henning S, Meisel C, Roots I (2000) Molecular genetics of cancer susceptibility. Pharmacology 61: 212-227.

18. Iwama K, Nakajo S, Aiuchi T, Nakaya K (2001) Apoptosis induced by arsenic trioxide in leukemia U937 cells is dependent on activation of $\mathrm{p} 38$, inactivation of ERK and the Ca2+-dependent production of superoxide. Int $\mathrm{J}$ Cancer 92: 518-526.

19. García-Chávez E, Santamaría A, Díaz-Barriga F, Mandeville $P$, Juárez BI, et al. (2003) Arsenite-induced formation of hydroxyl radical in the striatum of awake rats. Brain Res 976: 82-89.

20. Nandi D, Patra RC, Swarup D (2005) Effect of cysteine, methionine, ascorbic acid and thiamine on arsenic-induced oxidative stress and biochemical alterations in rats. Toxicology 211: 26-35.

21. Abernathy CO, Liu YP, Longfellow D, Aposhian HV, Beck B, et al. (1999) Arsenic: health effects, mechanisms of actions, and research issues. Environ Health Perspect 107: 593-597.

22. Stýblo M, Drobná Z, Jaspers I, Lin S, Thomas DJ (2002) The role of biomethylation in toxicity and carcinogenicity of arsenic: a research update. Environ Health Perspect 110 Suppl 5: 767-771

23. Duker AA, Carranza EJ, Hale M (2005) Arsenic geochemistry and health Environ Int 31: 631-641.

24. Basu A, Som A, Ghoshal S, Mondal L, Chaubey RC, et al. (2005) Assessment of DNA damage in peripheral blood lymphocytes of individuals susceptible to arsenic induced toxicity in West Bengal, India. Toxicol Lett 159: 100-112.

25. Hartmann A, Agurell E, Beevers C, Brendler-Schwaab S, Burlinson B, et al. (2003) Recommendations for conducting the in vivo alkaline Comet assay. 4th International Comet Assay Workshop. Mutagenesis 18: 45-51.

26. Yasuhara S, Zhu Y, Matsui T, Tipirneni N, Yasuhara Y, et al. (2003) Comparison of comet assay, electron microscopy, and flow cytometry for detection of apoptosis. J Histochem Cytochem 51: 873-885.

27. Sinkó I, Mórocz M, Zádori J, Kokavszky K, Raskó I (2005) Effect of cigarette smoking on DNA damage of human cumulus cells analyzed by comet assay. Reprod Toxicol 20: 65-71.

28. Malm-Erjefalt M, Stevens TR, Persson CGA, Erjefalt JS (2004) Discontinuous percoll gradient centrifugation combined with immunomagnetic separation obviates the need for erythrocyte lysis and yield isolated eosinophils with minimal granule abnormalities. J Immunol Methods 288: 99-109.

29. Akram Z, Jalali S, Shami SA, Ahmad L, Batool S, et al. (2009) Genotoxicity of sodium arsenite and DNA fragmentation in ovarian cells of rat. Toxicol Lett 190: 81-85.

30. Palus J, Lewinska D, Dziubaltowska E, Stepnik M, Beck J, et al. (2005) DNA damage in leukocytes of workers occupationally exposed to arsenic in copper smelters. Environ Mol Mutagen 46: 81-87.

31. Flora SJ, Mehta A, Rao PV, Kannan GM, Bhaskar AS, et al. (2004) Therapeutic potential of monoisoamyl and monomethyl esters of meso 2,3-dimercaptosuccinic acid in gallium arsenide intoxicated rats. Toxicology 195: $127-146$

32. Flora SJ, Mittal M, Pachauri V, Dwivedi N (2012) A possible mechanism for combined arsenic and fluoride induced cellular and DNA damage in mice. Metallomics 4: 78-90.

33. Yáñez L, García-Nieto E, Rojas E, Carrizales L, Mejía J, et al. (2003) DNA damage in blood cells from children exposed to arsenic and lead in a mining area. Environ Res 93: 231-240.

34. Vuyyuri SB, Ishaq M, Kuppala D, Grover P, Ahuja YR (2006) Evaluation of micronucleus frequencies and DNA damage in glass workers exposed to arsenic. Environ Mol Mutagen 47: 562-570.

35. Banerjee M, Sarma N, Biswas R, Roy J, Mukherjee A, et al. (2008) DNA repair deficiency leads to susceptibility to develop arsenic-induced premalignant skin lesions. Int J Cancer 123: 283-287.

36. Méndez-Gómez J, García-Vargas GG, López-Carrillo L, Calderón-Aranda ES 
Citation: Akram Z, Mahjabeen I, Kayani MA (2016) Assessment of Arsenic Induced DNA Fragmentation by using Comet Assay. J Carcinogene Mutagene 7: 258. doi:10.4172/2157-2518.1000258

Page 7 of 7

Gómez A, et al. (2008) Genotoxic effects of environmental exposure to arsenic and lead on children in region Lagunera, Mexico. Ann N Y Acad Sci 1140: 358367.

37. Jasso-Pineda Y, Díaz-Barriga F, Calderón J, Yáñez L, Carrizales L, et al. (2012) DNA damage and decreased DNA repair in peripheral blood mononuclear cells in individuals exposed to arsenic and lead in a mining site. Biol Trace Elem Res 146: 141-149.

38. Palus J, Lewińska D, Dziubałtowska E, Wasowicz W, Gromadzińska J, et al. (2006) Genotoxic effects in C57BI/6J mice chronically exposed to arsenate in drinking water and modulation of the effects by low-selenium diet. $\mathrm{J}$ Toxico Environ Health A 69: 1843-1860.

39. Ahmed MK, Mamun MH, Hossain MA, Arif M, Parvin E, et al. (2011) Assessing the genotoxic potentials of arsenic in tilapia (Oreochromis mossambicus) using alkaline comet assay and micronucleus test. Chemosphere 84: 143-149.

40. Gatti L, Cossa G, Tinelli S, Carenini N, Arrighetti N, et al. (2014) Improved apoptotic cell death in drug-resistant non-small-cell lung cancer cells by tumor necrosis factor-related apoptosis-inducing ligand-based treatment. J Pharmacol Exp Ther 348: 360-371.

41. Yoo DR, Chong SA, Nam MJ (2009) Proteome profiling of arsenic trioxide treated human hepatic cancer cells. Cancer Genomics Proteomics 6: 269-274.

42. Yedjou CG, Tchounwou PB (2007) In-vitro cytotoxic and genotoxic effects of arsenic trioxide on human leukemia (HL-60) cells using the MTT and alkaline single cell gel electrophoresis (Comet) assays. Mol Cell Biochem 1: 123-130.

43. Dopp E, von-Recklinghausen U, Hartmann LA Stueckradt L, Pollok I, et al (2008) Subcellular distribution of inorganic and methylated arsenic compounds in human urothelial cells and human hepatocytes. Drug Metab Dispos 36: 971 979

44. Graham B, Stevens J, Wells P, Sims J, Rogers C, et al. (2014) Enhancement of arsenic trioxide-mediated changes in human induced pluripotent stem cells. Int $\mathrm{J}$ Environ Res Public Health 11: 7524-7536.

45. Hossain MF (2006) Arsenic contamination in Bangladesh: an overview. Agri Ecosys Environ 113: 1-16.

46. Jan KY, Wang TC, Ramanathan B, Gurr JR (2006) Dithiol compounds at low concentrations increase arsenite toxicity. Toxicol Sci 90: 432-439.

47. Kryeziu K, Jungwirth U, Hoda MA, Ferk F, Knasmüller S, et al. (2013) Synergistic anticancer activity of arsenic trioxide with erlotinib is based on inhibition of EGFR-mediated DNA double-strand break repair. Mol Cancer Ther 12: $1073-1084$

48. Liu SY, Wen CY, Lee YJ, Lee TC (2010) XPC silencing sensitizes glioma cells to arsenic trioxide via increased oxidative damage. Toxicol Sci 116: 183-193.

49. Nakamura S, Nagano S, Nagao H, Ishidou Y, Yokouchi M, et al. (2013) Arsenic trioxide prevents osteosarcoma growth by inhibition of GLI transcription via DNA damage accumulation. PLoS One 8: e69466.

50. Pu YS, Jan KY, Wang TC, Wang AS, Gurr JR (2007) 8-Oxoguanine DNA glycosylase and MutY homolog are involved in the incision of arsenite-induced DNA adducts. Toxicol Sci 95: 376-382.

51. Qin XJ, Hudson LG, Liu W, Timmins GS, Liu KJ (2008) Low concentration of arsenite exacerbates UVR-induced DNA strand breaks by inhibiting PARP-1 activity. Toxicol Appl Pharmacol 232: 41-50.

52. Stevens JJ, Graham B, Walker AM, Tchounwou PB, Rogers C (2010) The effects of arsenic trioxide on DNA synthesis and genotoxicity in human colon cancer cells. Int J Environ Res Public Health 7: 2018-2032.

53. Wneck SM, Kuhlman CL, Camarillo JM, Medeirosa MK (2011) Interdependent genotoxic mechanisms of monomethylartsonous acid: ROS induced DNA damage and poly (ADP-ribose polymerase-1 inhibition in the malignant transformation of urothelial cells. Toxicol Appl Pharmacol 257: 1-13. 